\title{
BANKING: A POLITICAL ECONOMIC OVERVIEW
}

Ali TARHAN ${ }^{\star}$

\section{Abstract}

Banking business keeps its importance in an economy since the ancient times. Banking initially was not a reputable business. However, from the beginning of middle of the nineteenth century banking turned into a respectful business. This historical period also indicates the establishment of big investment banks in the United States (US). These investment banks made important contributions in development of the US by financing the big projects via securitizations in financial markets. The aim of this study is to examine the political powers of these big financial institutions.

Keywords: Political Economy, Power, Banking, Shadow Banking

\section{BANKACILIĞIN EKONOMI POLITiĞi}

\section{Öz}

Bankacllk sektörü eski çağlardan bu yana ekonomi içindeki önemini korumaktadır. Bankacılık başlangıçta toplumsal olarak kabul görmemiştir. Ancak bu meslek 19. Yüzylın ikinci yarısından başlayarak itibarlı hale gelmiştir. Bu tarihsel dönem

\footnotetext{
Dr., Specialist, Central Bank of the Republic of Turkey, Head Office 06100 Ankara, E-mail: alitarhan@gmail.com

The author would like to thank Assoc. Prof. C. Coşkun Küçüközmen, İzmir Economy University, Oya Kayaalp and the librarians of Bilkent University for their time and support to improve the quality of this paper.
} 
ayrıca, özellikle Amerika Birleşik devletleri'nde (ABD) büyük yałırım bankalarının kuruluşuna da işaret etmektedir. Bu yatıım bankaları borsalarda yaptıkları menkul kıymetleştirme işlemleriyle büyük projeleri finanse etmiş, dolayısıyla ABD'nin kalkınmasına önemli katkılarda bulunmuştur ve siyasi alanlarda da söz sahibi olmuştur. Çalışmanın amacını büyük finans kurumlarının siyasi güçlerinin ekonomi politik açıdan irdelenmesi oluşturmaktadır.

Anahtar Kelimeler: Ekonomi Politik, Güç, Bankacllik, Gölge Bankacillk

\section{INTRODUCTION}

The purpose of this study is to examine the banking system from a political economic perspective. Banking is a wellstudied field by various disciplines. Especially mainstream economics analyzes banking in two ways. The first one is macroeconomics. In macroeconomics banking and fund rising are the main financial sources of economic growth. These two components are also crucial parts of the general equilibrium in a given economy. In microeconomics, banking and its funds are vital parts of a firm's cash flow. However, mainstream economists have paid less attention to capital accumulations and power relations in these areas. Especially after the 2008 financial crisis it has become evident that banking is an enormous source of financial funds and political power. After the crisis, huge funds of extra-banking system have come to the attention of researchers. This extra-banking system is called shadow banking. Shadow banking has played two important roles before and after the crisis. These roles are becoming the initiator of the crisis and after the crisis evolving into its solution blocker. Needles to say, traditional and shadow banking owe this power to the weak regulations and deregulations in the US and the United Kingdom (UK). These two dominant powers of world financial system have always had enough might to set the rules and paradigms of the overall system. Consequently, the big financial institutions of these two countries have 
reached the peak of their economic and political power before the 2008 crisis. However, since the mainstream economics excludes power and class relations in its basic analysis, these two premises remained largely under examined by this discipline.

Political economy, on the other hand, maintains a broader scope and more holistic approach regarding mainstream economics. Therefore, political economy investigates every subject in its power and class relations arrangements. The consequence of this analysis is a broader understanding of the examined topic with its surrounding relationship networks. Thus, political economy is both a multidiscipline and interdisciplinary research area. Enormous financial distress of 2008 crisis has brought to the scene the need of intensive inquiries on current financial system, its fundamental faults, new solution proposals and the urgency of a new world financial architecture. However, economists could not reach a consensus over the nature of these problems, and the power of world banking system has easily prevented these questions from coming into the agenda. Nevertheless, these questions are yet to be answered. It is also obvious that an easy and urgent consensus among the mainstream and political economists is not a common expectation. Therefore, both groups will continue to investigate the topics on their own ways in the near future.

This study especially emphasizes the US and the UK banking systems for two reasons. First, the banking systems of these two countries are loosely regulated, or completely unregulated. Second, the mass volume of banking industry of these countries has a dominating role in world banking system. Therefore, these countries' banking systems give a laboratory to examine the banking in its untouched form. However, limited span of this study does not allow a detailed examination of these spacious subjects. Therefore, this study is limited with the key concepts of political economy and banking. 


\section{POLITICAL ECONOMY AND POWER}

James Steuart ([1767] 2013) is the first philosopher who coined the term political economy. Steuart, as in the ancient Greek philosophy, restricts economy for the private family business. Political economy, on the other hand, is to institutionalize and adapt the manners, habits and customs of the family for a state. Steuart's division of household and state economy is a turning point in the history of economics. In ancient Greek philosophy, beginning with Plato, there was no distinction between household and state economies (Bonar [1893] 1967). This division reigned along the classical epoch of political economy. This epoch refers a period from the middle of the eighteenth century through the middle of the nineteenth century alongside the industrial revolution (Duménil and Lévy 1999). According to Pressman and Neill (1999), until the middle of the nineteenth century, in the hands of Adam Smith, Jean-Babtiste Say, David Ricardo and John Stuart Mill political economy turned into a search of economic growth of the nations and the increase of welfare of their citizens. However, Mill ([1848] 1994) for the first time drew attention to the selfishness of privileged and powerful classes and their use of power in the interest of themselves. This advance marks the beginning and importance of the power analysis in political economy. Classical political economists divided the society in three classes as landowners, industrial capitalists and waged workers, and envisaged the possibility of conflicts among these three classes. However, their deep belief in markets' wealth ensuring and distributing features subdued the importance of their previsions (Realfonzo 1999). Until the Marxian analyses, class conflicts did not become a major issue in political economy.

After Alfred Marshall's Principles of Economics in 1890, political economy and economics have been largely divorced. Following the divorce, economics has evolved towards a mostly mathematical analysis. During this period, political economy has lost its brightness until the mid twentieth century. When the dissatisfactions became visible of the narrow focus 
of mainstream economics in the mid twentieth century, political economy has reached to a new stage. At this stage, political economy has started employing more concepts from neighboring disciplines in its analyses, and this trend still continues. The two most important concepts of this inclination are power and class relations.

From Machiavelli onward, power has been in the realm of political science. Regarding class relations, with the push of Marxist analyses, class would be in the realm of sociologists. Political economy has recovered with a brand new explanendum with Meuret (1988). Meuret defines political economy as the articulation of three forces within a society:

"If, at the end of eighteenth century, political economy became the prevailing representation of economic phenomena, this was due to the fact that, better than other economic or political discourses, it constructed a political framework in which three forces could co-exist. These forces were those that all the authors of this century tried to articulate: the state, capitalism, and those who tried to protect themselves from their power"

This definition emphasizes two strong points. First of all, this description is an apparent recognition of Gramscian hegemonic powers by political economy. Second, Meuret draws attention to the survival and power gaining processes of these three forces. Therefore, a complete political economic analysis requires an analysis of state, capitalism and ruling or ruled classes within an economy, or in international economy. The common denominator of struggle among these three phenomena is power.

Machiavelli ([1516] 1999), when he tries to explain power, illustrates the story of Agathocles as an ordinary Sicilian who eventually will become the king of Syracuse. Agathocles' achievements are based on his ignorance of public opinion and his cruel measures which carry him towards the anticipated end. According to Machiavelli, despite his cruelty,

Biçimlendirilmiş

Biçimlendirilmiş

Biçimlendirilmiş

Biçimlendirilmiş: Yazı tipi: 12 nk

Biçimlendirilmiş: Yazı tipi: 12

Biçimlendirilmiş: Yazı tipi: 12 nk

Biçimlendirilmiş: Yazı tipi: 12 nk

Biçimlendirilmiş: Yazı tipi: 12 nk

Biçimlendirilmiş: Yazı tipi: 12 $\mathrm{nk}$

Biçimlendirilmiş: Yazı tipi: 12 nk

Biçimlendirilmiş

Biçimlendirilmiş

Biçimlendirilmiş

Biçimlendirilmiş

Biçimlendirilmiş

Biçimlendirilmiş

Biçimlendirilmiş 
Agathocles reaches his endeavors; therefore, means justify the ends. Consequently, Machiavelli promotes the use of power without any value system (Strauss 1958). In other words, Machiavelli's power is a naked power unrestricted from any other internal set of assessments. Antonio Gramsci, on the other hand, elaborates the indirect use of power. Although his works remained mostly incomplete, they have later been organized and published by various researchers. Gramsci adds the ideological state apparatuses to the classical Marxian coercive state apparatuses which employ power within a society by various institutions, such as clergy, family, schools, and trade unions (Althusser 1976). In this indirect form of power, ruling classes establish a hegemonic sphere in order to amalgamate all the working classes, regardless of their ideology, identity or beliefs, in the same political stand (Ransome 1992). Therefore, with the aid of ideological apparatuses states use less coercive power on their citizens. This definition also implies the relative independency of a modern state within an invisible hegemonic circle.

Contemporary philosophers make further sophistications on the concept of power as a core phenomenon behind and under the main driving force of social and economic movements. Power is essentially someone's or some institutions' direct or indirect coercive ability over someone or some institution to do or not to do something. Likewise, Russell ([1938] 1969) defines power as the production of intended effects. Lukes (2005) draws attention, not in a Gramscian way though, to the securing the consent of subjects to be dominated. These two definitions indicate the evolution of power from a Machiavellian naked form to a more sophisticated structure. This situation causes identification and location problems of power in the minds of subservient people. According to Mills (2000) this dilemma of power of the common men "... are circumscribed by the everyday worlds in which they live, yet even in these rounds of job, family, and neighborhood they often seem driven by the forces they can neither understand nor

\begin{tabular}{|l|}
\hline Biçimlendirilmiş \\
\hline Biçimlendirilmiş \\
\hline Biçimlendirilmiş \\
\hline
\end{tabular}

Biçimlendirilmiş

Biçimlendirilmiş

Biçimlendirilmiş

Biçimlendirilmiş

Biçimlendirilmiş

Biçimlendirilmiş

Biçimlendirilmiş

Biçimlendirilmiş

Biçimlendirilmiş

Biçimlendirilmiş

Biçimlendirilmiş

Biçimlendirilmiş

Biçimlendirilmiş 
govern." The expression of modern power and power relations, as Mills portrays, is almost invisible to the ordinary men. Consequently, ordinary men cannot change their subservient position since they cannot recognize and challenge the source of Biçimlendirilmiş

Biçimlendirilmiş power.

Arendt's (1970) works also underpin Mills' approach, and distinguishes power from strength. According to Arendt, power is not an individualistic phenomenon. Power always belongs to certain groups and, as long as these groups exist, power remains as an active entity. Therefore, these groups empower certain individuals. Thus, the power of an individual actually refers to the power of a certain group which delegates a part of its authority to this individual. In contrary, strength is an individual property. Mills and Arendt expose some important characteristics of modern power: indirectness, invisibility and anonymity. These outcomes play an important role in economic analyses and, through Meuret's definition, power also regains a distinctive role in political economy.

However, power analyses have played no major role in economics in the first half of the twentieth century. Mainstream or neoclassical economics has paid little or no attention to power and other neighboring disciplines (Kesting 2005). One of the best examples of this point of view comes from Russell ([1938] 1969) who states that economic power is taken for granted and it is not principal as in military power. Speaking of international relations, insignificant economic conflicts are solved by laws, and the major ones by war. Within the states, greater part of economic power belongs to individuals. In Russellian perspective, in modern Western countries economic and political powers are separated. Where these two forces coalesced are totalitarian states. This approach has found a place for itself among the mainstream economists. However, during the course of the time, especially beginning with the second half of the twentieth century, economists have changed their positions on the power in economy, mostly due to the ever increasing impacts of the cold war. Consequently,

\begin{tabular}{|l|} 
Biçimlendirilmiş \\
Biçimlendirilmiş \\
\hline Biçimlendirilmiş \\
\hline Biçimlendirilmiş \\
\hline Biçimlendirilmiş \\
\hline Biçimlendirilmiş \\
\hline Biçimlendirilmiş \\
\hline
\end{tabular}


researches of this era focused on power balances and game theory. A good example of this consideration comes from Hirshleifer (1990). Hirshleifer defines power as someone's capacity to achieve his ends in a competitive environment. This competitive atmosphere suggests that every party will struggle for power at every level of competition. In order to achieve this end, every competitor must establish a balance between his productive and conflictive activities. The fate of this struggle depends on the resources of the competitors devoted to productive activity and the commitments to conflictual activity.

Economics discipline owes its reunion with the concept of power to John Kenneth Galbraith's works. Galbraith introduced countervailing and conditioning powers to the theory of economics. According to Galbraith, consumers balance the market power of oligopolistic entrepreneurs. The power accumulated in the hands of few strong people creates a countervailing result within the side of less powerful people. This happens almost automatically by the forces of free markets (Kesting 2005). However, countervailing power does not completely neutralize the power center. Once countervailing power emerges, both sides try to acquire the support of the government in order to gain superiority over the other party. Conditioning power, on the other hand, works with persuasion in a society and hinders the visibility of power. Thus, conditioning power is the modern face of the Machiavellian power. At this stage power diffuses among the individuals, in an Arendtian medium, so that consumers or other targets of power cannot locate its source, and remain subordinated. With this analysis, Galbraith integrates social and economic forces of society around the axis of power.

Bardhan (1991) further elaborates Galbraith's portrayal of implicit power, and uncovers the unquestioningly acknowledged market relations. According to Bardhan, trading parties within an agreed judicial and economic system may benefit from their transactions. However, if one of the parties has forcibly defined the rules and institutions of this system in a long for-
Biçimlendirilmiş

Biçimlendirilmiş

Biçimlendirilmiş

Biçimlendirilmiş

Biçimlendirilmiş

Biçimlendirilmiş

Biçimlendirilmiş

Biçimlendirilmiş

Biçimlendirilmiş

Biçimlendirilmiş

Biçimlendirilmiş

Biçimlendirilmiş

Biçimlendirilmiş

Biçimlendirilmiş

Biçimlendirilmiş 
gotten time ago, this side may gain an inherent and undiscovered supremacy over the other side. Once a party has established its hegemonic superiority in the markets, power relations within this system may asymmetrically survive for a long unnoticed period, and when discovered may cause open or covert conflicts. Bardhan exemplifies this situation with enclosure movement in England and disrespect of the US government to the tribal rights of native Indians in the nineteenth century.

Galbraith and Bardhan's analyses shift focus from visible to invisible power relations. However, this shift creates the problems of defining, locating, interrelating and measuring problems in these relations. Another problem comes forth from constantly sophisticated interactions of economic and political powers melt in an uneasily identified pot. Oliver (1979) categorizes these questions in four groups. The first question comes from both economic and political systems' interrelationships. These interrelationships do not always unveil themselves. Causations and power sources cannot be easily located, and these hardships block the easy answers. Second, the concepts of economics and politics are flexible. These concepts are abstract by nature, and their flexibility drags the analyses from theoretical levels to the relevancy seeking fields. The third problem comes from the sharp distinction between the concrete and abstract study fields. Abstract study fields are prone to more abstractions and this trend may create barriers for the effective applications of abstract theories into the concrete phenomena. The last problem is the existence of variable causation routes among the economic and political phenomena which rules out the production of all-encompassing theories. Oliver's sophisticated network of power relations and their hard to grasp nature makes power analyses further complicated.

These analyses can be summarized as follows. First of all, history of economics has witnessed the evolution of power from the Machiavellian robber barons of the nineteenth century to modern executive boards. During this journey power has taken more implicit forms, and these forms have showed

\section{Biçimlendirilmiş}

Biçimlendirilmiş

Biçimlendirilmiş

Biçimlendirilmiş

Biçimlendirilmiş

Biçimlendirilmiş

Biçimlendirilmiş

Biçimlendirilmiş

Biçimlendirilmiş

Biçimlendirilmiş

Biçimlendirilmiş

Biçimlendirilmiş

Biçimlendirilmiş

Biçimlendirilmiş

Biçimlendirilmiş

Biçimlendirilmiş

Biçimlendirilmiş

Biçimlendirilmiş

Biçimlendirilmiş 
themselves as Galbraithian countervailing and conditioning forces. Galbraithian countervailing and conditioning forces have entailed close economic and political relationships of power groups with governments in order to gain supremacy. Consequently, as in Meuret's definition, those who cannot gain the support of neither the government nor the capital find themselves in a defensive position.

\section{TRADITIONAL BANKING}

Bankers and financiers have always had an important place in the state mechanisms, though not all the time been respected. According to Sheppard (1861) bankers and state treasurers belonged to the top first class out of four in ancient Roman Empire. The existence of bankers and banking in Greece and Rome during the ancient times is known, however; detailed knowledge about this era is still unavailable. The roots of modern banking can be traced as early as in the eleventh century and thirteenth centuries in Europe. In medieval ages, mint makers and goldsmiths made great fortunes and, with the aid of these fortunes, turned themselves into feudal nobles or local gentry (Lopez 1979). The distinctive feature of medieval banking was its acceptance as an ungentlemanly business due to the Bible's provisions on interest and usury. This dilemma of needing the sources of bankers and keeping them at a low place of the social ladder reigned until the disappearance of this disharmony in the late nineteenth century in British Empire. Between 1890 and 1914, 51 percent of the bankers were educated in private or red brick schools in Britain. The higher education of bankers eased their acceptance by the aristocratic classes and they have been formally recognized as the primary cause of prosperity and wealth of the country (Cassis 1985).

Traditional banking is the formally institutionalized form of money borrowing and lending business. Therefore, banks are the intermediaries between the depositors and borrowers. The
Biçimlendirilmiş

Biçimlendirilmiş

Biçimlendirilmiş: Yazı tipi: Kalın

Biçimlendirilmiş

Biçimlendirilmiş

Biçimlendirilmiş

Biçimlendirilmiş

Biçimlendirilmiş

Biçimlendirilmiş

Biçimlendirilmiş

Biçimlendirilmiş

Biçimlendirilmiş

Biçimlendirilmiş 
need for an intermediary rises from two sources. First, the lack of appropriate information between the lenders and borrowers hinders most of the transactions. Second, borrowers and lenders may have diverse liquidity and maturity inclinations (Heffernan 1996). Banking industry fulfills these gaps and provides adequate information for interested parties and matches their

Biçimlendirilmiş

Biçimlendirilmiş

Biçimlendirilmiş liquidity and maturity preferences in a financial pool. Moreover, banking industry provides guarantees for trading parties and safeguards the future of transactions.

Figure 1 illustrates how the traditional banking system works. In step A, individuals or firms make deposits at banks and receive guarantees against these funds. These funds are the primary sources of traditional banks. In the second step, B, banks lend these funds to borrowers and receive mortgages or notes as collaterals. Both transactions can be followed in banks' balance sheets. In this simple banking form, banks' fund creation abilities are limited (Gorton and Metrick 2009).

Figure 1. Traditional Banking System

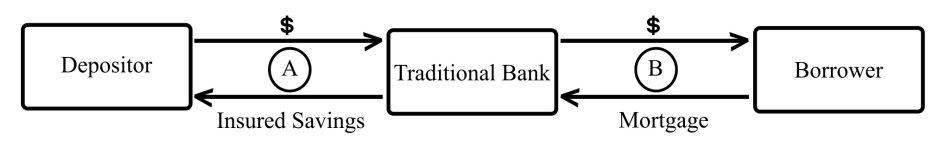

Source: Gordon and Metrick 2009

This limited ability of traditional banks in fund raising has opened the era of investment banking in the US. Commercial banks evolved into the investment banks beginning in the second half of the nineteenth century due to the rise of prosperity. The first actors in US' financial system were German immigrant bankers such as the Seligmans, the Lehmans, Solomon Loeb and Marcus Goldman (Feeney 1995). Investment banking 
evolved in three steps. In the first step, they underwrote the funds for non-financial companies and governments which traditional banks could not afford, by issuing securities. Later, they entered into broking and portfolio management business. At the last stage, they entered the business restructuring via managing or orchestrating the mergers and acquisitions (Rycbczynski 1996). In the US, investment banking separated from commercial banking with the Securities Act and the Securities Exchange Act in 1933 and 1934 respectively (Friedman and Schwartz 1963). After that date, while commercial banking was heavily regulated, investment banking enjoyed an unregulated financial environment. During this period, regulatory structure of the UK remained unbiased.

Securitization is the primary business of investment banks. Securitization is a wholesale form of banking and can be broadly defined as a specialized intermediation on money rising by issuing securities in capital and money markets (Feeney 1995). Investment banks may issue commercial papers and bonds in these markets. This is the primary form of securitization. This form of securitization can be seen as assets in the balance sheets of investment banks. However, investment banks may go further and securitize these loans one more time, and sell them in bond markets. This is called secondary securitization. In secondary securitization, these assets disappear from the balance sheets of investment banks. Figure 2 shows this transaction.

Step 1 in Figure 2 is similar to the step A in Figure 1 with one exception. In Figure 1 deposits of the customers are insured by the government agencies to a certain amount. In the securitization process, depositors transfer their money to the banks and acquire repurchase agreements (repo/s). Unlike the traditional banking, in securitization process banks do not directly lend these funds to borrowers. Instead, they fund the direct lenders in step 2. Direct lenders fund the borrowers and receive mortgages in step 3 . In step 4 banks securitize these mortgages and receive cash. At the end of these transactions

\begin{tabular}{|l|}
\hline Biçimlendirilmiş \\
\hline Biçimlendirilmiş \\
\hline Biçimlendirimlendirimiş \\
\hline Biçimlendirilmiş \\
\hline \\
\hline Biçimlendirilmiş \\
\hline
\end{tabular}

Biçimlendirilmiş

Biçimlendirilmiş

Biçimlendirilmiş

Biçimlendirilmiş

Biçimlendirilmiş

Biçimlendirilmiş

Biçimlendirilmiş

Biçimlendirilmiş

Biçimlendirilmiş

Biçimlendirilmis 
banks theoretically reach their starting points. However, the total value of the repos issued by intermediaries is less than the total amount of their face value. When banks sell repos they apply a discount on them. This special discount is called as "haircut". Within this financial circle all actors are big players except borrowers. Therefore, securitization markets are wholesale markets.

Figure 2. Securitization

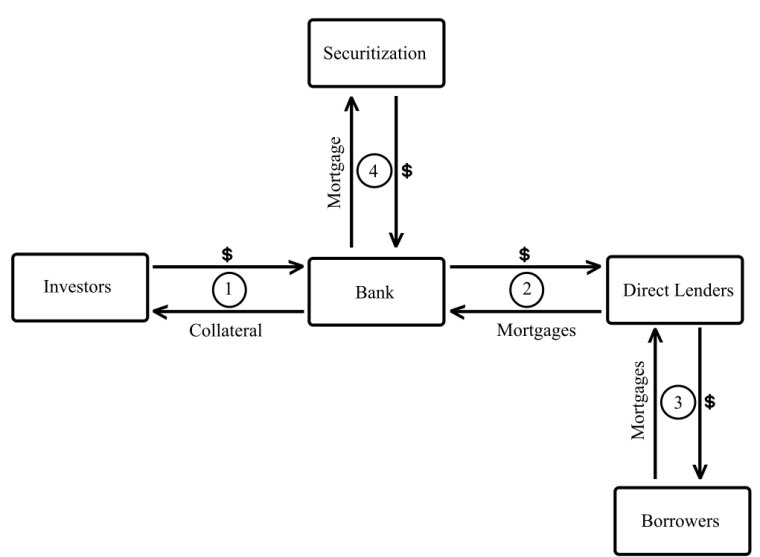

Source: Gorton and Metrick 2009

Banking, especially investment banking has always had an important effect in financing the development and big projects. Developed countries of today owed their positions to their investment banks and solidity of financial markets. Success of investment banking in the US and the UK also enhances the explanations on developmental questions for the rest of developing world. By this logic, the lack of investment banking and efficient bond markets in developing countries reveal the continuing underdevelopment and investment shortages in these countries. Once a commercial bank in a developing country places its funds in the loan markets, its loanable sources melt down. In order to attract more deposits and replenish its liquidity up to an acceptable level, at least for its daily cash flow and cash demands, this bank has to offer
Biçimlendirilmiş

Biçimlendirilmiş

Biçimlendirilmiş

Biçimlendirilmiş: Yazı tipi: Kalın

Biçimlendirilmiş

Biçimlendirilmiş

Biçimlendirilmiş 
higher interest rates on deposits. On the other hand, rising interest rates make new investments less profitable or completely impossible in the long run. If this bank choices to fund its clients with overseas sources it has to pay a risk margin above the money market interest rates. Even in this case, costly funding makes the investments less profitable in this country, and its entrepreneurs lose their productivity against their foreign competitors.

\section{SHADOW BANKING}

Shadow banking system has different definitions based on the point of view of the researchers. One of the formal definitions comes from The Financial Stability Board (FSB). A FSB (quoted in Errico et al 2014) paper defines the shadow banking system as "credit intermediation involving entities and activities (fully or partially) outside the regular banking system" or nonbank credit intermediation. In a later report FSB (2012) describes shadow banking as "credit intermediation involving entities and activities outside the regular banking system." Unlike the traditional banking, the network created by the shadow banking system has only a small number of links with the real economy (Gallin 2013). Gorton and Metrick (2010) define shadow banking system as securitization process with different regulations and players. Distinctive feature of the shadow banking is complete lack of regulation. Process of shadow banking is realized within the private jurisprudential realm without the government inspection. Primary shadow banking institutions are investment banks, mortgage brokers, money-market mutual funds (MMMFs). Instruments of this system cover repos, assetbacked securities, collateralized debt obligations, and assetbacked commercial papers. Figure 3 explains the working of this system.

In step 1, the system begins to work. In step 1, MMMFs sell their shares to retail investors and lend these funds to the banks and receive collaterals in step 2. In step three, banks fund the 
private borrowers and receive loans. Banks sell these loans to special purpose vehicles (SPVs) and receive cash and securitized bonds. SPVs are privately created legal entities in the forms of corporations or limited liability companies. An SPV acts as a pool for the assets invested in it. In fact, it is fictive firm which houses huge assets to sell them in bulk amounts to MMFs, and more importantly, is immune to the US bankruptcy laws due to its private judicial structure. In step 5, SPVs sell their securitized bonds to MMFs. MMFs again sell these securities to retail investors. Shadow banking transactions are realized by very short term repos. Therefore, this system also uses some hair cuts on circulating securities depending on the risks carried by them. Hair cut rates varied around 20 percent when the system was not so widespread and reliable. But, at the heights of shadow banking hair cut rates get closer to zero percent due to the overconfidence and greediness of players of the financial markets, and this overconfidence made the whole system prone to margin calls. Most infamous example of this situation was the bankruptcy of Lehman Brothers. As the system began to collapse, Lehman Brothers could not respond to the margin calls and bankrupted. This unexpected bankruptcy triggered the 2007-2008 financial crises.

Biçimlendirilmiş

Biçimlendirilmiş

Biçimlendirilmiş

Figure 3. The Shadow Banking System 


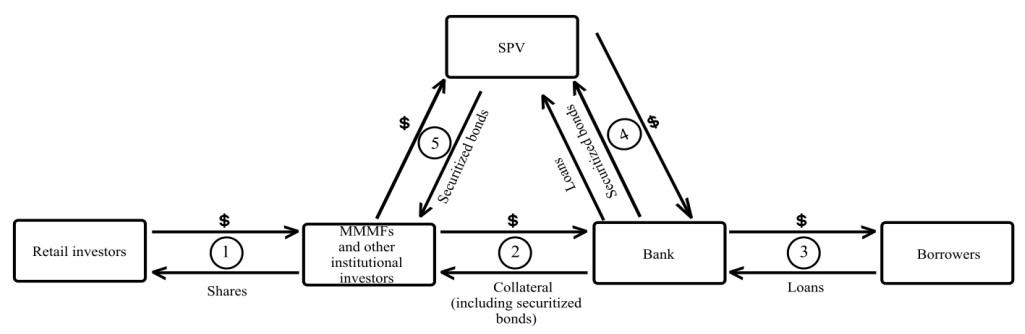

Source: Gorton and Metrick 2010.

Principally, shadow banking is not a funding system for real economy due to the short term nature of its funds. This explains the weak ties between the shadow banking and real economy. Primary investors of shadow banking are institutions and corporations which have large amounts of daily excess or idle funds. They invest these excess funds on MMFs on a daily basis during the normal times. However, during the 2008 financial turmoil many MMFs and SPVs were unable to respond margin calls coming from the banks and their chain bankruptcies devastated the daily cash flows of real economy corporations. This explains why real economy in the US and UK faced common financial distortions and bankruptcies during and after the crisis despite their weak ties with shadow banking system.

\section{A POLITICAL ECONOMIC APPRAISAL AND CONCLUSION}

Biçimlendirilmiş: Yazı tipi: Kalın

Commercial and investment banks in the US and the UK made enormous contributions on the development of these two countries beginning with the mid nineteenth century. The institutional and judicial structures of banking systems in these countries enabled them to mobilize their internal savings in development projects. The most important judicial contribution comes from the Anglo-Saxon law system. Anglo-Saxon law system is based on negative rights. Negative rights system which

Biçimlendirilmiş

Biçimlendirilmiş

Biçimlendirilmiş

Biçimlendirilmiş

Biçimlendirilmiş allows virtually everything unless forbidden by the law enables and encourages individuals to make contracts between them. 
The law also ensures the unbreakable nature of these contracts. This also enables individuals to make their trade in a judicially safe environment and promotes further commercial activities. However, Ilchman and Bhargava (1973) indicate that this mobilization could not be possible without the aids and consensuses of ruling elites in these countries. Ilchman and Bhargava draw attention to these non-economic factors behind the development and identify two types of ruling elites distinguished by membership. The first types of elites come from private sector and play important roles in government agencies as civil servants. These types of elites are called as modernizing elites. The second type elites are the heavy representation of businessmen in governmental platforms. The latter ones are especially active in decision making processes. Both types represent a narrow membership.

Ilchman and Bhargava's approach is consistent with Mills (2000) and Arendt (1970). The decisive point of numerically small power groups is their almost unrecognizable existences. However, this invisibility does not make them less powerful. On the contrary, less visible power group becomes more powerful. Burt (2001) elaborates this approach as structural holes. In order to bring the fore of these groups' hidden might, Burt distinguishes social capital from human capital. Social capital is established by certain people who have certain ties with each other. Mutually established trust connects these people. These ties enable group members to concentrate their powers into their desired ends and make them more powerful compared to the rest of the society.

Banking industry in the US has established its social capital within the governmental mechanism directly or indirectly. Direct methods are clearly visible. Especially, beginning with the globalization era, investment banks' managers have played important roles in crucial federal agencies, such as Federal Reserve System and US Treasury. This enabled financial system to be directly involved in decision making mechanisms of the federal government. Indirect form of power using is lobbying.

\begin{tabular}{|l|}
\hline Biçimlendirilmiş \\
\hline Biçimlendirilmiş \\
\hline Biçimlendirilmiş
\end{tabular}

Biçimlendirilmiş

Biçimlendirilmiş

Biçimlendirilmiş

Biçimlendirilmiş

Biçimlendirilmiş

Biçimlendirilmiş

Biçimlendirilmiş

Biçimlendirilmiş

Biçimlendirilmiş

Biçimlendirilmiş 
Lobbying is a familiar process in representative democracies and does not necessarily carry a negative connotation provided that it is realized among the equal parties (Besley and Coate 2001). However, powers of contesting lobbies seldom coincide and more powerful party may have a more preferential conclusion for itself over the others. Consequently, economically powerful lobbies may influence, even bribe the politicians on favor of themselves (Campos and Giovannoni 2007). Therefore, the powers of political influence of corporations or social networks are closely related to the economic power of these groups. Braun \& Raddatz emphasize that this interrelatedness between the politicians and power groups affect the whole economy through interfering the credit allocation processes.

According to a FSB (2012) report, financial assets of the shadow banking system of the US reached \$23 trillion in 2011. Euro area followed the US with \$22 trillion, and the UK with \$9 trillion. On the other hand, shadow banking system in these areas is operated by a handful of big investment and commercial banks. Therefore, these figures show the impossibility of emergence of Galbraithian countervailing forces within these districts. Consequently, big financial institutions of these countries remain unchallenged and inequitable. The inaction of the US federal government and its involuntariness to regulate the shadow banking system after 2008 crisis also gives a clue about the political might of big financial institutions. This crisis also revealed the role of big investment banks in international capital flows, especially between the core and the peripheral countries (Tarhan 2013). While the US and the UK investment banks have composed the core of the world financial system, peripheral countries have been represented by their insistent current account deficits and low taxation. Current account deficits and poor internal revenues of peripheral countries have originated the asymmetrical financial relations between core countries. Within this asymmetrical relationships structure, big investment banks have grasped the opportunity of discreetly

\begin{tabular}{|l|}
\hline Biçimlendirilmiş \\
\hline Biçimlendirilmiş \\
\hline Biçimlendirimlendirişişiş \\
\hline Biçimlendirimlendiş \\
\hline \\
\hline Biçimlendirilmiş \\
\hline Biçimlendirilmiş
\end{tabular}

Biçimlendirilmiş

Biçimlendirilmiş

Biçimlendirilmiş

Biçimlendirilmiş

Biçimlendirilmiş

Biçimlendirilmiş

Biçimlendirilmiş

Biçimlendirilmiş

Biçimlendirilmiş 
exercising their financial might over the peripheral countries. Within this framework, the masses cited in Meuret's work continue to remain feeble.

\section{REFERENCES}

Althusser, L. 1976. Essays on Ideology. London: Verso

Arendt, H. 1970. On Violence. New York: Harcourt Brace Javanovich.

Bardhan, P. 1991. "On the Concept of Power in Economics." Economics and Politics 3 (3): 265-277.

Besley, T. and S. Coate. 2001. "Lobbying and Welfare in a Representative Socjety." TheReview of Economic Studies 68 (1): 67-82.

Bonar, J. (1893) 1967. Philosophy and Political Economy. London: George Allen \& Unwin.

Braun, M, and Raddatz, C. 2010. "Banking on Politics: When Former Highranking Politicians Become Bank Directors." The World Bank Economic Review 24 (2): 234-279.

Burt, R. S. 2001. "The Social Capital of Structural Holes" In New Directions in Economic Sociology. Edited by: Mauro F. Guillén and Marshall Meyer. Reprint. New York: Russell Sage Foundation.

Campos, N. F., and F. Giovannoni. 2007. "Lobbying, Corruption and Political Influence." Public Choice 131 (1/2): 1-21.

Cassis, Y. 1985. "Bankers in English Society in the Late Nineteenth Century." The Economic History Review 38 (2): 210-229.

Duménil, Gérard, and D. Lévy. 1999. "Classical political economy." In Encyclopedia of Political Economy. Edited by Phillip Anthony O'Hara, 109111. London: Routledge.

Feeney, P. W. 1995. Securization. London: St. Martin's Press.

Friedman, Milton and A. J. Schwartz. 1963. A Monetary History of the United States, 1867-1960. Princeton: Princeton University Press.

Financial Stability Board. 2012. Global Shadow Banking Monitoring Report 2012. Washington, DC.

Gallin, J. 2013. Shadow Banking and the Funding of the Nonfinancial Sector. Working paper, Federal Reserve Board, Washington, DC.

\begin{tabular}{|c|c|}
\hline Biçimlendirilmiş & $\ldots[1]$ \\
\hline Biçimlendirilmiş & $\ldots[2]$ \\
\hline Biçimlendirilmiş & $\ldots[3]$ \\
\hline Biçimlendirilmiş & $\ldots[4]$ \\
\hline Biçimlendirilmiş & $\ldots[5]$ \\
\hline Biçimlendirilmiş & $\ldots[6]$ \\
\hline Biçimlendirilmiş & $\ldots[7]$ \\
\hline Biçimlendirilmiş & $\ldots[8]$ \\
\hline Biçimlendirilmiş & $\ldots[9]$ \\
\hline Biçimlendirilmiş & 10] \\
\hline Biçimle & [11] \\
\hline Biçimlendirilmiş & [12] \\
\hline Biçimlendirilmiş & [13] \\
\hline Biçimlendirilmiş & $\ldots[14]$ \\
\hline Biçimlenc & $\ldots[15]$ \\
\hline Biçimlendirilmiş & $\ldots[16]$ \\
\hline Biçimlendirilmiş & {$[17]$} \\
\hline Biçimlendirilmiş & 18] \\
\hline Biçimlendirilmiş & $\ldots[19]$ \\
\hline Biçimlendirilmiş & $\ldots[20]$ \\
\hline Biçimlendirilmiş & 1] \\
\hline Biçimlendirilmiş & $\ldots[22]$ \\
\hline $\mathrm{Biç}$ & $\ldots[23]$ \\
\hline Biçimlendirilmiş & $\ldots[24]$ \\
\hline Biçimlendirilmiş & $\ldots[25]$ \\
\hline Biçimlendirilmiş & $\ldots[26]$ \\
\hline Biçi & $\ldots[27]$ \\
\hline Biçimlendirilmiş & $\ldots[28]$ \\
\hline Biçimlendirilmiş & $\ldots[29]$ \\
\hline Biçimlendirilmiş & $\ldots[30]$ \\
\hline Biçimleı & [31] \\
\hline Biçimlendirilmiş & [32] \\
\hline Biçimlendirilmiş & 33] \\
\hline Biçimlendirilmiş & $\ldots[34]$ \\
\hline Biçimlendirilmiş & $\ldots[35]$ \\
\hline Biçimlendirilmiş & [36] \\
\hline Biçimlendirilmiş & $\ldots[37]$ \\
\hline
\end{tabular}


Gorton, G. B., and A. Metrick. 2009. Securitized Banking and the run on Repo. Working paper, National Bureau of Economic Research, Cambridge, MA.

Gorton, G. B., and A. Metrick. 2010. "Regulating the Shadow Banking System." Brookings Papers on Economic Activity (Fall): 261-312.

Heffernan, S. 1996. Modern Banking in Theory and Practice. Chichester: John Wiley and Sons.

Hirshleifer, J. 1990. The Determinants of power. Working paper, University of California, Los Angeles.

Ilchman W. F. and R. C. Bhargava. 1973. "Balanced Thought and Economic Growth." In The Political Economy of Development and Underdevelopment. Edited by Charles K. Wilber, 26-54. New York: Random House.

Kesting, S. 2005. "Countervailing, Conditioned, and Contingent: The Power Theory of John Kenneth Galbraith." Journal of Post Keynesian Economics 28 (1): $3-23$.

Lopez, R. S. 1979. The Dawn of Medieval Banking. New Haven and London: Yale University Press.

Luca E., A.Harutyunyan, E.Loukoianova, R. Walton, Y.Korniyenko, G.Amidžić, $\mathrm{H}$.

AbuShanab, H. Song Shin. 2014. Mapping the Shadow Banking System through a Global Flow of Funds Analysis. Working paper, International Monetary Fund, Washington, DC.

Lukes, S. 2005. Power A Radical View. Hampshire: Palgrave Macmillan.

Machiavelli, N. (1516) 1999. The Prince. Translated by George Bull. London: Penguin.

Meuret, D. 1988. "A political genealogy of political economy." Translated by Graham Burchell, Economy and Society 17 (2): 225-250.

Mill, J. S. (1848) 2013. Principles of Political Economy. Oxford: Oxford University Press.

Mills, C. W. 2000. The Power Elite. Oxford: Oxford University Press.

Oliver, H. 1979. "Study of Relationships between Economic and Political Systems." In The Economy as a System of Power. Edited by Warren J. Samuels, 209-21 $\overline{7}$. New Brunswick: Transaction Books.

\begin{tabular}{|c|c|}
\hline $\begin{array}{l}\text { Biçimlendirilm } \\
\mathrm{nk}\end{array}$ & pi: 10 \\
\hline $\begin{array}{l}\text { Biçimlendirilmiş } \\
\mathrm{nk}\end{array}$ & tipi: 10 \\
\hline $\begin{array}{l}\text { Biçimlendirilmi } \\
\mathrm{nk}\end{array}$ & 0 \\
\hline Biçimlendirilmiş & $\ldots[38]$ \\
\hline Biçimlendirilmiş & $\ldots[39]$ \\
\hline Biçimlendirilmiş & $\ldots[40]$ \\
\hline Biçimlendirilmiş & $\ldots[41]$ \\
\hline Biçimlendirilmiş & $\ldots[42]$ \\
\hline Biçimlendirilmiş & $\ldots[43]$ \\
\hline Biçimlendirilmiş & $\ldots[4$ \\
\hline Biçimlendirilmiş & $\ldots[45]$ \\
\hline Biçimlendirilmiş & $\ldots[46]$ \\
\hline Biçimlendirilmiş & $\ldots[47]$ \\
\hline Biçimlendirilmiş & $\ldots[48]$ \\
\hline Biçimlendirilmiş & $\ldots[49]$ \\
\hline Biçimlendirilmiş & $\ldots[50]$ \\
\hline Biçimlendirilmiş & $\ldots[51]$ \\
\hline Biçimlendirilmiş & $\ldots[52]$ \\
\hline Biçimlendirilmiş & $\ldots[53]$ \\
\hline Biçir & $\ldots[54]$ \\
\hline Biçimle & $\ldots[55]$ \\
\hline Biçimlendirilmiş & $\ldots[56]$ \\
\hline Biçimlendirilmiş & $\ldots$ \\
\hline Biçi & $\ldots[58]$ \\
\hline Biçimlendirilmiş & $\ldots[59]$ \\
\hline Biçimlendirilmiş & $\ldots[60]$ \\
\hline Biçimlendirilmiş & 1] \\
\hline Biçimlendirilmiş & $\ldots[62]$ \\
\hline Biçimlendiriln & $\ldots[63]$ \\
\hline Biçimlendirilmiş & $\ldots[64]$ \\
\hline Biçimlendirilmiş & $\ldots[65]$ \\
\hline Biçimlendirilmiş & $\ldots[66]$ \\
\hline Biçimlendirilmiş & 57] \\
\hline
\end{tabular}


Pressman, S., and R. Neill. 1999. "Political economy." In Encyclopedia of Political Economy. Edited by Phillip Anthony O'Hara, 853-856. London: Routledge.

Ransome, P. 1992. Antonio Gramsci: A New Introduction. New York: Harvester-Wheatsheaf.

Realfonzo, R. 1999. "Political Economy: History." In Encyclopedia of Political Economy. Edited by Phillip Anthony O'Hara, 856-861. London: Routledge.

Russell, B. (1938) 1969. Power. New York: Norton.

Rycbczynski, T. M. 1996. "Investment banking: its evolution and place in the financial system." In Investment Banking, Theory and Practice. Edited by: Edward Gardener and Philip Molyneux, 1-13. London: Euromoney Books.

Steuart, J. (1767) 2013. Political Economy. Reprint: Rare Books Club.

Sheppard, J. G. 1861. Fall of Rome and the Rise of the New Nationalities: London: Routledge, Warne, \& Routledge.

Strauss, L. 1958. Thoughts on Machiovelli. Chicago: The University of Chicago Press.

Tarhan, A. 2013. "Financial Crises and Center Periphery Capital Flows." Journal of Economic Issues XLVII (2): 411-418.
Biçimlendirilmiş: Yazı tipi: 10 $\mathrm{nk}$

Biçimlendirilmiş: Yazı tipi: 10 $\mathrm{nk}$

Biçimlendirilmiş: Yazı tipi: 10 nk

Biçimlendirilmiş: Yazı tipi: 10 nk

Biçimlendirilmiş: Yazı tipi: 10

$\mathrm{nk}$

Biçimlendirilmiş: Yazı tipi: 10 $\mathrm{nk}$

Biçimlendirilmiş: Yazı tipi: 10

nk

Biçimlendirilmiş: Yazı tipi: 10 nk

Biçimlendirilmiş: Yazı tipi: 10 nk

Biçimlendirilmiş: Yazı tipi: 10 $\mathrm{nk}$

Biçimlendirilmiş: Yazı tipi: 10 nk

Biçimlendirilmiş: Yazı tipi: 10

Biçimlendirilmiş: Yazı tipi: 10 nk

Biçimlendirilmiş: Yazı tipi: 10 nk

Biçimlendirilmiş: Yazı tipi: 10 nk 
Sayfa 177: [1] Biçimlendirilmiş

ieu

28.03.2014 13:36:00

Biçimlendirilmiş

Sayfa 177: [2] Biçimlendirilmiş

Yazı tipi: Kalın

Sayfa 177: [3] Biçimlendirilmiş

Yazı tipi: $10 \mathrm{nk}$

Sayfa 177: [4] Biçimlendirilmiş

Yazı tipi: $10 \mathrm{nk}$

Sayfa 177: [5] Biçimlendirilmiş

Yazı tipi: $10 \mathrm{nk}$

Sayfa 177: [6] Biçimlendirilmiş ieu
Yazı tipi: $10 \mathrm{nk}$

ieu

28.03.2014 13:36:00

Sayfa 177: [7] Biçimlendirilmiş ieu

28.03.2014 13:36:00

Yazı tipi: $10 \mathrm{nk}$

Sayfa 177: [8] Biçimlendirilmiş

ieu

28.03.2014 13:36:00

Yazı tipi: $10 \mathrm{nk}$

Sayfa 177: [9] Biçimlendirilmiş

ieu

28.03.2014 13:36:00

Yazı tipi: $10 \mathrm{nk}$

Sayfa 177: [10] Biçimlendirilmiş ieu

28.03.2014 13:36:00

Yazı tipi: 10 nk, İtalyanca (İtalya)

Sayfa 177: [11] Biçimlendirilmiş ieu

28.03.2014 13:36:00

Yazı tipi: $10 \mathrm{nk}$

Sayfa 177: [12] Biçimlendirilmiş
Yazı tipi: $10 \mathrm{nk}$

Sayfa 177: [13] Biçimlendirilmiş ieu

ieu

28.03.2014 13:36:00

Yazı tipi: $10 \mathrm{nk}$

Sayfa 177: [14] Biçimlendirilmiş ieu

28.03.2014 13:36:00

Yazı tipi: $10 \mathrm{nk}$

\begin{tabular}{|c|c|c|}
\hline Sayfa 177: [15] Biçimlendirilmiş & ieu & 28.03.2014 13:36:00 \\
\hline \multicolumn{3}{|l|}{ Yazı tipi: $10 \mathrm{nk}$} \\
\hline Sayfa 177: [16] Biçimlendirilmiş & ieu & 28.03.2014 13:36:00 \\
\hline \multicolumn{3}{|l|}{ Yazı tipi: $10 \mathrm{nk}$} \\
\hline Sayfa 177: [17] Biçimlendirilmiş & ieu & 28.03.2014 13:36:00 \\
\hline \multicolumn{3}{|l|}{ Yazı tipi: $10 \mathrm{nk}$} \\
\hline Sayfa 177: [18] Biçimlendirilmiş & ieu & 28.03.2014 13:36:00 \\
\hline \multicolumn{3}{|l|}{ Yazı tipi: $10 \mathrm{nk}$} \\
\hline Sayfa 177: [19] Biçimlendirilmiş & ieu & 28.03.2014 13:36:00 \\
\hline \multicolumn{3}{|l|}{ Yazı tipi: $10 \mathrm{nk}$} \\
\hline Sayfa 177: [20] Biçimlendirilmiş & ieu & 28.03 .2014 13:36:00 \\
\hline \multicolumn{3}{|l|}{ Yazı tipi: $10 \mathrm{nk}$} \\
\hline Sayfa 177: [21] Biçimlendirilmiş & ieu & 28.03.2014 13:36:00 \\
\hline \multicolumn{3}{|l|}{ Yazı tipi: $10 \mathrm{nk}$} \\
\hline Sayfa 177: [22] Biçimlendirilmiş & ieu & 28.03.2014 13:36:00 \\
\hline \multicolumn{3}{|l|}{ Yazı tipi: $10 \mathrm{nk}$} \\
\hline Sayfa 177: [23] Biçimlendirilmiş & ieu & 28.03 .2014 13:36:00 \\
\hline Yazı tipi: $10 \mathrm{nk}$ & & \\
\hline
\end{tabular}


Sayfa 177: [24] Biçimlendirilmiş

Yazı tipi: $10 \mathrm{nk}$ ieu

28.03.2014 13:36:00

Sayfa 177: [25] Biçimlendirilmiş ieu

28.03.2014 13:36:00

Yazı tipi: 10 nk, Almanca (Almanya)

Sayfa 177: [26] Biçimlendirilmiş

ieu

28.03.2014 13:36:00

Yazı tipi: $10 \mathrm{nk}$

Sayfa 177: [27] Biçimlendirilmiş

ieu

28.03.2014 13:36:00

Yazı tipi: $10 \mathrm{nk}$

Sayfa 177: [28] Biçimlendirilmiş ieu

28.03.2014 13:36:00

Yazı tipi: $10 \mathrm{nk}$

Sayfa 177: [29] Biçimlendirilmiş

ieu

28.03.2014 13:36:00

Yazı tipi: $10 \mathrm{nk}$

Sayfa 177: [30] Biçimlendirilmiş

ieu

28.03.2014 13:36:00

Yazı tipi: $10 \mathrm{nk}$

Sayfa 177: [31] Biçimlendirilmiş

ieu

28.03.2014 13:36:00

Yazı tipi: $10 \mathrm{nk}$

Sayfa 177: [32] Biçimlendirilmiş

Yaz1 tipi: $10 \mathrm{nk}$

Sayfa 177: [33] Biçimlendirilmiş

ieu

28.03.2014 13:36:00

Yazı tipi: $10 \mathrm{nk}$

Sayfa 177: [34] Biçimlendirilmiş

Yazı tipi: $10 \mathrm{nk}$

Sayfa 177: [35] Biçimlendirilmiş

Yazı tipi: $10 \mathrm{nk}$

Sayfa 177: [36] Biçimlendirilmiş

Yazı tipi: $10 \mathrm{nk}$

Sayfa 177: [37] Biçimlendirilmiş ie
Yazı tipi: $10 \mathrm{nk}$

ieu

28.03.2014 13:36:00

ieu

28.03.2014 13:36:00

Sayfa 178: [38] Biçimlendirilmiş

Yazı tipi: $10 \mathrm{nk}$

Sayfa 178: [39] Biçimlendirilmiş

Yazı tipi: $10 \mathrm{nk}$

Sayfa 178: [40] Biçimlendirilmiş

Yazı tipi: $10 \mathrm{nk}$

Sayfa 178: [41] Biçimlendirilmiş

ieu

28.03.2014 13:36:00

ieu

28.03.2014 13:36:00

ieu

28.03.2014 13:36:00

Yazı tipi: $10 \mathrm{nk}$

Sayfa 178: [42] Biçimlendirilmiş

Yazı tipi: $10 \mathrm{nk}$

Sayfa 178: [43] Biçimlendirilmiş ieu
Yazı tipi: $10 \mathrm{nk}$

ieu

28.03.2014 13:36:00

ieu

28.03.2014 13:36:00

ieu

28.03.2014 13:36:00

ieu

28.03.2014 13:36:00

Sayfa 178: [44] Biçimlendirilmiş ieu ieu

28.03.2014 13:36:00

Yazı tipi: $10 \mathrm{nk}$

Sayfa 178: [45] Biçimlendirilmiş

Yazı tipi: $10 \mathrm{nk}$
28.03.2014 13:36:00

28.03.2014 13:36:00

28.03.2014 13:36:00

28.03.2014 13:36:00 
Yazı tipi: $10 \mathrm{nk}$

Sayfa 178: [47] Biçimlendirilmiş ieu

Yazı tipi: $10 \mathrm{nk}$

Sayfa 178: [48] Biçimlendirilmiş ieu

28.03.2014 13:36:00

Yazı tipi: $10 \mathrm{nk}$

\begin{tabular}{lll}
\hline Sayfa 178: [49] Biçimlendirilmiş & ieu & $\mathbf{2 8 . 0 3 . 2 0 1 4 ~ 1 3 : 3 6 : 0 0}$ \\
Yazı tipi: $10 \mathrm{nk}$ & & \\
\hline Sayfa 178: $[50]$ Biçimlendirilmiş & ieu & $\mathbf{2 8 . 0 3 . 2 0 1 4} 13: 36: 00$ \\
Yazı tipi: $10 \mathrm{nk}$ & &
\end{tabular}

Sayfa 178: [51] Biçimlendirilmiş ieu

28.03.2014 13:36:00

Yazı tipi: $10 \mathrm{nk}$

Sayfa 178: [52] Biçimlendirilmiş

ieu

28.03.2014 13:36:00

Yazı tipi: $10 \mathrm{nk}$

Sayfa 178: [53] Biçimlendirilmiş ieu

Yazı tipi: $10 \mathrm{nk}$

Sayfa 178: [54] Biçimlendirilmiş

ieu

28.03.2014 13:36:00

Yazı tipi: $10 \mathrm{nk}$

Sayfa 178: [55] Biçimlendirilmiş ieu

Yazı tipi: $10 \mathrm{nk}$

Sayfa 178: [56] Biçimlendirilmiş

ieu

28.03.2014 13:36:00

Yazı tipi: $10 \mathrm{nk}$

Sayfa 178: [57] Biçimlendirilmiş

ieu

28.03.2014 13:36:00

Yazı tipi: $10 \mathrm{nk}$

Sayfa 178: [58] Biçimlendirilmiş

ieu

28.03.2014 13:36:00

Yazı tipi: 10 nk, Fransızca (Fransa)

Sayfa 178: [59] Biçimlendirilmiş

ieu

28.03.2014 13:36:00

Yazı tipi: $10 \mathrm{nk}$

\section{Sayfa 178: [60] Biçimlendirilmiş}

Yazı tipi: $10 \mathrm{nk}$

Sayfa 178: [61] Biçimlendirilmiş

Yazı tipi: $10 \mathrm{nk}$

Sayfa 178: [62] Biçimlendirilmiş

ieu

28.03.2014 13:36:00

Yazı tipi: $10 \mathrm{nk}$

Sayfa 178: [63] Biçimlendirilmiş

Yazı tipi: $10 \mathrm{nk}$

Sayfa 178: [64] Biçimlendirilmiş

ieu

28.03.2014 13:36:00

Yazı tipi: $10 \mathrm{nk}$

Sayfa 178: [65] Biçimlendirilmiş

Yazı tipi: $10 \mathrm{nk}$

Sayfa 178: [66] Biçimlendirilmiş

ieu

28.03.2014 13:36:00

Yazı tipi: $10 \mathrm{nk}$

Sayfa 178: [67] Biçimlendirilmiş

ieu

28.03.2014 13:36:00

Yazı tipi: $10 \mathrm{nk}$

ieu

28.03.2014 13:36:00

ieu

28.03.2014 13:36:00

ieu

28.03.2014 13:36:00

ieu

28.03.2014 13:36:00 